\title{
Ecofeminist Horizons
}

\author{
Isabella Lamas \\ Stefania Barca \\ Bernadete Souza Ferreira \\ Ivonne Yanez
}

${ }^{\text {I }}$ Universidade da Integração Internacional da Lusofonia Afro-Brasileira (Unilab), Bahia, Brasil

D II Universidade de Santiago de Compostela (Espanha) e Centro de Estudos Sociais da Universidade de Coimbra, Portugal

${ }^{I I I}$ Central Estadual de Associações das Comunidades da Agricultura Familiar e Campesina do Estado da Bahia (CECAF), Bahia, Brasil

IV Acción Ecológica, Quito, Equador

Abstract: Decolonial political ecology embodies far more than mere critique. Rather, decolonial political ecologies allow us to advance transformative proposals, to articulate sophisticated reflections on emancipatory practices, and, above all, to re-imagine future scenarios and horizons. These imagined horizons were articulated by three women from different social contexts: Bernadete Souza Ferreira Santos, a ialorixá peasant and specialist in Rural Education and Agroecology from USP, who works as a 'popular educator' in the region of Ilhéus (southern Bahia); Ivonne Yanez, an environmental activist from Ecuador and one of the founders of the organization Acción Ecologica; and Stefania Barca, a scholar in feminist political ecology, originally from Naples (Italy), and currently working at the Centre for Social Studies at the University of Coimbra (Portugal). Together, they show us the paths towards emancipatory horizons that can be found at the intersection between Political Ecology and feminism.

Keywords: Ecofeminism; political ecology; anthropocene; alternatives; agroecology; environmental justice

São Paulo. Vol. 24, 2021

Narratives and Reflections: Decolonial Insurgences and Emancipatory Horizons

DOI: http://dx.doi.org/10.1590/1809-4422asoc20210153vu2021L5NR 
Decolonial political ecology embodies far more than mere critique. Rather, decolonial political ecologies allow us to advance transformative proposals, to articulate sophisticated reflections on emancipatory practices, and, above all, to re-imagine future scenarios and horizons. In this light, the closing of the III Latin American Congress of Political Ecology - 'Emancipatory Horizons' - was organized to evoke collective reflection on past, present, and future paths towards socio-environmental justice as the common, ultimate objective.

These imagined horizons were articulated by three women from different social contexts: Bernadete Souza Ferreira Santos, a ialorixá peasant and specialist in Rural Education and Agroecology from USP, who works as a 'popular educator' in the region of Ilhéus (southern Bahia); Ivonne Yanez, an environmental activist from Ecuador and one of the founders of the organization Acción Ecologica; and Stefania Barca, a scholar in feminist political ecology, originally from Naples (Italy), and currently working at the Centre for Social Studies at the University of Coimbra (Portugal). Together, they show us the paths towards emancipatory horizons that can be found at the intersection between Political Ecology and feminism.

From these different perspectives, the three contributions collected here express how patriarchy, capitalism, and colonialism perpetuate inequalities and systems of domination in modern/colonial society. Patriarchal masculinity not only underlies the Man/Nature dichotomy, it also enables the objectification of nature as raw material to be exploited for industrial consumption - an essential process for the propagation of colonialism and the advance of capitalism. Over time, "ecofeminist thought and praxis have revealed the connections of gender inequality, sexism, racism, classism, the North-South divide, and environmental deterioration" (Puleo, 2020, w/p). Ecofeminism emerged precisely from this encounter between the common concerns and agendas of both the feminist and ecology movements. Beginning in Europe in the 1970s, the Ecofeminist movement initially focused on the unequal global distribution of environmental hazards that disproportionately affected women. Today, women's status as 'victims' has largely been rejected and replaced with the image of women as the main protagonists of popular ecological struggles worldwide. In particular, these struggles are embedded within the language and the ethics of care - as women embrace this as the crucial starting point in the fight against environmental degradation.

Centralizing the women's struggle in ecological discussions necessarily implies engaging with a plurality of feminisms. Our panel has sought to do just that by including the views of a black Brazilian feminist and leader of Candomblé, a religion of the African Matrix, an Ecuadorian feminist environmental activist, and an Italian eco-feminist researcher. These women's collective reflections on 
Political Ecologies teaches us that our so-called 'emancipatory horizons' are inherently ecofeminist.

\section{Bernadete Souza Ferreira Santos:}

I am a peasant, settled in the Tear Dom Helder Câmara in Ilhéus, an agrarian reform settlement. I am also part of the State Center of Associations of Family Farming Communities and Peasants of the State of Bahia (CECAF), and three days ago I joined the leadership of the Intersyndical of the Rural Secretariat at the national level.

I would like to salute two women warriors who left us this year, both on the day before yesterday: Mãe Stella de Oxóssi and Makota Valdina. They both fought so hard for the environment and, more specifically, for the preservation of the tradition of the African matrix religions.

At this moment, having this discussion here, in this space, is very interesting for us, as peasants, due to what is happening in our country: a setback and loss of our rights, where men and women are dying and the environment and biodiversity are auctioned off to those who want to see the destruction of this planet. I think that we cannot point towards the future without having these debates, without organizing ourselves as Brazilian people.

The countries that are there, the Latin American countries, are the ones that are suffering this moment where, as we say, "the steamroller" of world politics is wanting to finish them off, especially when the environment is at stake.

Historically, here in our country, governments consider the rural environment as a place of deprivation. It is a place of backwardness, economically, politically, and culturally. This idea only serves to strengthen agribusiness and large landowners. We know that, every day, agribusiness expels men and women from the countryside and from their own lands. We find the result of this in the big cities, as they swell up with expatriated peasants. Agribusiness has appropriated income, expropriated peasants from their land, exploited workers, devastated forests and common goods, and seized control over water and biodiversity, privatizing them for the market. We have seen this shift in the result of the new elections, with the military now taking charge of the environmental and INCRA departments.

The model of rural development that we have here in our country is the development of monoculture. So, we see the big latifundia with soy, with cattle, with big corn plantations, with transgenic plantations. Native seeds are not valued in our country, since it is the peasants who do this preservation. (...) And this monoculture model needs to be immediately broken by us, because we know that this government will only strengthen it, fueling the great perversity it is doing to our country.

So, it is a model of perversity because it is development for one specific group, not for us, peasants. The agrotoxics that are thrown into the land and the planet only 
bring death, they do not bring life to anyone. Even previous, leftist administrations in our country embraced the development of agribusiness, with a minister once claiming: if the Brazilian population wants to eat more, then they have to eat poison, because the Brazilian population cannot afford to eat organic products.

But when we talk about agroecology, we talk about a development model that opposes this perverse model. And we, peasants, we do agroecology, yes! It is not only organic products that today have become "fashionable" - and I don't mean this in a negative sense,. Yet the problem is that once the farmers who produce this organic product take it to the market, the price is so absurd that, in fact, the working class ends up not being able to consume it and must eat canned and packaged agribusiness products instead. So, when we give our children, our grandchildren, for example, dairy flour, where does this product come from? How was it produced? Have we stopped to think about the beans we eat? The amount of poison that is put in this product? The degree of poison in soy and in the food we consume today is so high that research says that each Brazilian consumes 7 liters of poison per year. So, how can wehave "sustainable development" within this existing capitalist model? We really need to defend a new form of sustainable development for our planet. And when we talk about sustainable development and agroecology, it is much broader than simply organic products. Because agroecology is around all of us, from our homes, animals, the fauna and flora. That is, in general, in people's lives.

In general, we need a sustainable model with social balance, where we must overcome the accumulation matrix of capital. And, we cannot think of a sustainable model, a model that opposes agribusiness, such as agroecology, if we do not have this debate, for example, when we talk about the issue of diversity. The debate takes place even in the countryside, contradicting its image as a place of backwardness, we in the countryside are debating issues of machismo, homophobia, intolerance, patriarchy, racism, homophobia, xenophobia, because this is what we understand as sustainability. Agroecology should be included in these debates as any other social/political/economic issue. We need to discuss this in the countryside and, of course, in the city, because if the city and the countryside are not united, there is no development, neither agroecological nor social, at least not for our people - the people from the countryside and the working class, both in the countryside and in the city.

Another thing that we cannot and must not let go of is the issue of water, because we are seeing how, around the world, our planet and our people are dying because of what private corporations and agribusiness is doing with water. This includes the theft of groundwater, the big dams, the big invasions of the companies inside these spaces, and the Amazon.

I cannot help but speak as an Ialorixá and a religious leader of African origin, regardless of whether there are people of different religions here or people who do not 
have any religion, because our country is diverse, because for us orixá is the essence of nature. Orixa is the water, the earth, the woods, the stones, the wind, everything that is around us, this is the essence of the orixás. And we worship in a traditional way, through environmental preservation. We have the obligation to preserve the environment, because by preserving the environment we are respecting our religion, we are respecting the orixás. It is a religion that worships nature, that worships the environment. However, we are going through a very serious and difficult moment - the issue of religious intolerance, especially in relation to us, the religions of African origin.

To finish my speech, I would also like everyone here at this moment to shout with me. Because I am a black woman, a feminist woman, a woman of African descent, and March 14th marks a year since the execution of a black woman, a woman of African descent, a lesbian woman, a socialist woman, Marielle Franco. Our rallying cry is "Marielle Presente", "Marielle Presente", "Marielle Presente".

\section{Ivonne Yanez:}

Ecuador is a small country with some great ideas. But in Ecuador, what we like to do most of all is to provoke. We provoke presidents to leave. We like to provoke. I think it's because we are small that we like to be a bit of a nuisance. So, I'm going to do that a little bit today and I'm going to talk about a topic that for many of us may be a good idea when we think about horizons. But, in reality, I believe that it can also sometimes be a trap that we fall into. WhatI'm talking about is the theme of alternatives. There are many working groups, including the ones we are a part of, that are "development alternatives". There is always talk about alternative energy. This is like saying that alternatives are something that have to be invented, when, in reality, alternatives exist everywhere. Candomble is a cultural alternative, (non-industrial) agriculture and fishing are recognized alternatives.... All these cultural and life practices that already exist are now called alternatives. Why?

I will compare extractivism to violence against women using the theme of 'alternatives' and you will see precisely why. The thing is, that when a community says: "we don't want mining", what happens? The state, the companies, the intermediary NGOs come and tell them, "Well, fine, you don't want mining, so what is your alternative?" And, of course. The communities say: "Our way of living, this is our alternative. The only alternative is no mining. But, the state, or the companies, they're not satisfied with that answer. So, they demand that they be given an alternative. And why do I want to compare it to violence against women? I want to show what "alternative" means in a context of resistance. If a woman says "I don't want you to touch my body without my consent," imagine a scenario where the abusive man says to her, "You don't want me to touch you, so what's the alternative?" No, what is the alternative? This is so ridiculous, so absurd, that I think this is precisely what the companies and the state are instigating 
when they suggest that the people's chosen way of life is the so-called 'alternative', while mining is the norm.

Another thing I wanted to mention with respect to both this issue of alternatives and violence against women is consultation. Of course, it is the peoples' right to be consulted. But consultation only pertains its value so long as their voice is taken into account - the fact that they don't want mining activities, or oil activities, or anything of the sort. Because if not, the consultation becomes a test and a sham. What happens when a community says, "We don't want mining"? They say, "Well, it doesn't matter, we'll consult them anyway, but without it being a legally binding decision". What happens then? Regardless of the outcome of the consultation - more often than not, the communities reject mining - the interested company or government will carry on their initial agenda as if nothing happened, completely violating the peoples' right to self-determination. If a woman is asked by a man, "Can I touch you?" He is consulting, fair enough. But if a woman says "I don't want you to," [and he says] "It doesn't matter now, I'm doing it anyways." Then what's going on? It's sexual assault, without consent, in the case of the territories on the part of the State and/or the mining company, and in the case of the women on the part of a sexual assaulter. So, the consultation is simply a sham. Obviously, the same as with the alternatives.

I will end by saying why I have referred to this so much. Because I believe that oftentimes we are distracted - the organizations, the communities - thinking that the horizon is a distant horizon that we can hardly see. Let's put a horizon right here, in the first row. Inquiry. This is the horizon of our organizations and communities. With this it will be possible to fulfill the peoples' right to reject mining and to live in a healthy environment, and in the way they choose to live. The alternatives are a bit further, but they say "We are going to present you with all the alternatives you ask for", when in reality the only alternative we want is for the company to not even enter our territories and our communities in the first place.

I'm speaking from my position as a part of an Andean ecologist organization in Ecuador. I have 30 years of experience in defending nature, the rights of nature, and in fighting together with communities for their collective rights. I made the comparisons to violence against women to highlight that the horizon we have to walk through is precisely the union between ecological struggles with feminist struggles. Ecofeminism. Yes, the future and the horizon have to be ecofeminist, because if not, it wouldn't be a horizon we should even walk towards. I even like a made-up word that is not ecofeminism, but femi-ecologism. Because I am an ecologist, but I incorporate feminism. Just as feminists incorporate ecological struggles. So, from femi-ecologism, I think we can really find ways towards this horizon that we all want to walk on today.

\section{Stefania Barca:}


My contribution is to think about how academic work can help to create and enable emancipatory horizons. And I will do this by speaking of the Anthropocene. (...) This word, "Anthropocene", seems to be a rather strange word, a word of scientific criteria that has very little to do with struggle. In fact, this is a term with a very important political dimension because this is the name that the global scientific community, a scientific community that has been recognized by power in recent years, is calling our epoch: the epoch of climate change, the epoch of the destruction of life. Fortunately, in fact, because this is at least better than denying climate change.

Naming is a political act, it is appropriating something. And when we are naming a geological epoch that encompasses not only us, but all living things, it becomes an act of colonization. Everyone is being encompassed by this expression, the Anthropocene. And the Anthropocene thus represents the big house, the master's house. As the poet and activist Audre Lorde said, "the master's house has to be dismantled so that everyone can be free. Only, this dismantling will never happen with the master's tools. We need new tools to dismantle the Anthropocene and free ourselves from this oppressive narrative that constrains the possibilities of re-existence. This is my thesis.

The video "Welcome to the Anthropocene" was broadcast at the opening of Rio $+20^{1}$. The world climate meeting, where everybody was there to discuss climate policies, was opened by this video that explained that the Anthropocene was the starting point of the climate crisis - painting this as the scientific version of the story, one nobody could contest. This video has several things for us to discuss. The first is the use of the word "humanity", the use of the word "we". What the video describes is a homogeneous humanity. What the voice says is, "You and I, we are all part of this Anthropocene. Welcome to the Anthropocene." So, what is the idea? That we are all involved in the same way, and we, as humanity, are all responsible for these changes that have caused climate change. Another issue to question is science and technology as forces that have brought humanity on par with geological forces. Humanity, with science and technology, has managed to transform the climate, even geology. This is a celebration of power. While, on the one hand, this power can be destructive, the power of science and technology is also depicted as salvation, which will allow us to come out of this crisis in the same way that we went into it. And the third thing is this celebration of the progress of humanity, where all the violence, the inequality are hidden, and the last fifty years are presented as an era in which 7 billion people have reached a wonderful standard of living. Only 1 billion people are malnourished, but that's it. It was worth it, that is the message we hear.

This shows us how this scientific concept has been used as a name, a title for a narrative that is eco-modernizing, but also neocolonial and hegemonic, that represents humanity as a geological force. But this narrative is not fundamentally new. This is 
just a new chapter in a hegemonic discourse, the discourse of modern economic growth that is the religion of our age. And this narrative of modern economic growth already existed and celebrated science and technology without calculating the environmental costs. So, the novelty of this chapter is: we have environmental costs, but we can solve them. That will be solved. So, this concept of the Anthropocene does not question this representation of the growth of material production beyond the biophysical limits of non-renewable resources as an undisputed achievement of European ingenuity, of the white man, in the name of humanity, for the advantage of all humanity. So, it is a neocolonial discourse. Ultimately this indisputable conquest, this historical conquest of the white man, translates into planetary supremacy, into a justification of the white man's planetary supremacy. This narrative is now rearticulated in this new mantra of green growth. Growth does not need to be questioned to become green.

From the perspective of Political Ecology, the Anthropocene effectively represents the ideology of the so-called post-political. This perspective allows us to visualize how so-called natural phenomena are socially constructed and reflect power asymmetries. In this case, to call the Anthropocene as such means to make invisible the fact that it was not all of humanity that caused climate change, but the capitalist, racist, patriarchal and human-supremacist system that has governed our planet since the beginnings of colonialism in the 16th century.

What is the perspective of feminist Political Ecology? What does feminism add to Political Ecology? The idea is that it is necessary to undo this concept of the Anthropocene, to show how it represents the white man's narrative, a masculinist and racist narrative. That is, this narrative is the story told by the master in the colonial, patriarchal, classist and human-supremacist sense of the term. The head of the farm, of the factory, of the trading company, the slave owner, the holder of legal authority over women, animals, and colonized subjects. This is the historical subject that tells us the story of the Anthropocene.

And it will be necessary, therefore, to deconstruct that narrative and construct, or rather, let emerge, a counter-narrative, an anti-master narrative of this historical epoch. The story of those who do not identify with the white man, nor with the science and technology of colonial capitalist modernity. This other narrative - this is my argument - will always emerge from the perspective of reproduction and care work, what I call the "forces of reproduction." That is, I am pointing to the historical agency of those subjects who, through both everyday practices, knowledge, and organized, political action, take care of the biophysical conditions for human and non-human reproduction and, by doing so, keep the world alive.

I have brought here stories from the world of work - especially from the 20th century. They are stories that tell us that labor, whether it is called reproduction, domestic or subsistence labor, or production labor (this distinction between production and 
reproduction is, by the way, part of the problem), has contributed in an organized way (because all these images represent political movements) to the ecological revolution. It is what Ivonne was saying, that the alternatives are not in the future, they are already part of our history, part of the history that is not that of the master, it is this other history.

My first story is that of the Green Belt movement in Kenya led by the scientist Wangari Maathai who received the Nobel Peace Prize. She was an agrarian scientist who came from a rural community and who was the first woman in her community to have access to education and get a University degree in agrarian science. And she understood that the impoverishment of her community during the 1980s in Kenya had everything to do with the deforestation of the country and the degradation of the land at the hands of multinational companies. So, she started this Green Belt movement with women from her own community, women who no longer knew how to feed their families, their children, because the land no longer produced the food that it traditionally used to produce. So, the women organized a reforestation movement against the powers that be. They occupied their own country's very soil by planting trees, and they were persecuted by all means, they were beaten by the police, they were imprisoned. They were many and they were determined because they understood that the trees and the standing forest were the only way to continue to sustain their own communities. They also did this in the name of their country. And in the end, this struggle won, and they were recognized and managed to reforest many areas. There are forests in Kenya today that were planted in the 1980s by them.

My second story is that of the environmental justice movement in the US, which started with Black and Latina women fighting for the health and wellbeing of their communities, whose very survival was threatened by industrial toxicity. Because these communities, as it just so happens everywhere, had been singled out as dump-sites for toxic waste and many other things which were not only damaging people's health but also destroying local soils and resources. So, they were the ones who started to mobilize against this by pointing to waste management as a form of racial discrimination. And this is a struggle that persists today - although it has achieved some important legislative reforms that, in essence, set a precedent for other communities to continue challenging the environmental injustice they face at the hands of companies and states. This has not always led to victory, but it was very important, for example, to be able to advance the Superfund legislation.

My third story is that of Zé Cláudio Ribeiro da Silva and Maria do Espirito Santo, in the agroecology project Praialta Piranheira in the South of Pará. For me, they represent the movement for community conservation in Brazil, which was also a very important struggle that has enabled these different forms of production and reproduction, these forms that are autonomous from the capitalist system. And, being victims themselves, Zé Cláudio and Maria also represent all the difficulties and the violence 
faced by earth-defenders. It is a story that began in the 1980s and is still very important for this country and for the whole world. When I speak in other contexts - you already know this story very well and I won't repeat it here - but when I speak in Europe and other countries, I always tell this story to say: "Look, we don't need to invent anything, other ways of coexisting with nature and producing and living well with nature already exist. These struggles have already been made, we have examples. What we need is to listen to these stories. And people are very open to knowing this, because these are the stories you don't find in textbooks, in formal education, in schools and in universities. So, people grow up with the idea that there are no alternatives, that alternatives have to be invented.

What I am trying to argue is that, for the ecological revolution, we need unity between the forces of production and the forces of reproduction. And this unity has to lead to changing relations, not only relations of production, but also relations of reproduction.

To conclude, the problem with the concept of the Anthropocene is that it not only invisibilizes the asymmetries - the power differences that are well rooted within humanity - it not only invisibilizes the violence hidden within progress and modernity, but it also invisibilizes the different potentialities of humanity. And therefore the Anthropocene renders the possible worlds, the not-yet worlds of humanity, effectively impossible. The ecological revolution is not only in the future, but in the present and in the history experienced by countless subjects of production and reproduction who have designed and practiced alternatives and who have struggled to defend and advance them. Sometimes succeeding, sometimes not. Always being the target of oppression, of silencing, and of violence at the hand of the master. The role of Political Ecology as a militant research practice is to support and enable ecological revolution. This begins by undoing this master narrative of the Anthropocene and enabling an alliance, I would say unity, between the forces of production and reproduction in an emancipatory socio-ecological horizon.

\section{The horizons are ecofeminist}

Bernadete Ferreira tells us about agroecology's struggle for survival against monoculture and agribusiness. She tells us how peasants are fighting against this growing development model, struggling to preserve native seeds, to ensure production without pesticides, and, most importantly, for the development of a new form of sustainable development.

And this sustainable model incorporates and is constituted through diversity; through the understanding that to talk about the environment is also to talk about machismo, homophobia, intolerance, patriarchy, racism, homophobia, and xenophobia. As part of Candomblé, a religion of African matrix, she highlights the connection of this form of faith with environmental preservation to reaffirm 
the importance of respect for socio-environmental diversity and religious tolerance. Bernadete proposes a collective tribute to Makota Valdina, who, like her, was also an Ialorixá and environmentalist. For Makota,

The people from Candomblé have a lot to contribute to humanity. When we fight to preserve the bush, that bush won't only serve those who are Candomblé members. When we take care of the water, we aren't only taking care of those from Candomblé. When we fight for the environment, we understand the environment in a much broader sense - not only as the natural environment, but also as relationships, as the interactions between people... In essence, we are fighting for peace in the world. (...) Racism and prejudice are environmental problems. Because they cause problems in human interactions. (...) How can we have peace in a racist, unfair, unequal society, full of prejudice, homophobia, and hunger? This, for me, is talking about the environment as well." Makota Valdina, in the documentary Jardim das Folhas Sagradas.

Candomblé practices are an "alternative" that already exists in the present, as pointed out by Ivonne Yanez. From her experience in an Andean ecologist organization in Ecuador, she says that when discussing alternatives to development, we commonly fall prey to the idea that we must invent these alternatives, forgetting that they already exist, from Candomble cultural practices, to nonindustrial fishing and agriculture. Drawing a parallel between extractivism and violence against women, Ivonne argues that our emancipatory horizon is the unity between ecological and feminist struggles, articulated precisely around the idea that communities have the right to say no to extractive mega-projects.

Stefania Barca draws our attention to the fact that we need new tools to free ourselves from the hegemonic, oppressive, eco-modernizing, neocolonial, sexist, and racist narrative of the Anthropocene that restricts our possibilities of existence and resistance. From a feminist Political Ecology perspective and an understanding of labor as the political subject of the global ecological revolution, a counter-narrative emerges. This counter-narrative centers on the forces of reproduction; that is, on the historical agency of those subjects who ensure the biophysical conditions necessary for both human and non-human reproduction. Thus, struggles for autonomy and the commons, such as those of Zé Cláudio and Maria, of the working classes and of ecofeminists, represent ecological revolutions that highlight existing alternatives. Stefania argues that Political Ecology - as a form of militant inquiry - paves the path towards the ecological revolution. From a feminist perspective that centralizes the women's struggle, this begins by undoing the narrative of the Anthropocene and by creating an alliance between the forces of production and reproduction, in an emancipatory horizon. 
The struggle for dignified living conditions for all people is incomplete without an ethics of care - both for human beings and for the natural world. Together, the three women's speeches reveal that Ecofeminism is precisely what lies at the heart of an emancipatory horizon towards the defense of the commons and of the environment.

\section{Acknowledgements}

The realization of this closing session of the III Latin American Congress of Political Ecology was supported by Capes and CNPQ. The editors and the publisher would like to thank the student Júlia Mota de Brito for transcribing part of the contents of the table and Giulia Armiero (giulia.armiero@gmail. com) for the translation.

\section{References}

PULEO, Alicia H. Ecofeminismo: a perspectiva de gênero na consciência ecológica. QG Feminista, 2020. Disponível em: https://medium.com/qg-feminista/ecofeminismoa-perspectiva-de-g\%C3\%AAnero-na-consci\%C3\%AAncia-ecol\%C3\%B3gica432a34535e69. Acesso em 3 de maio de 2021. 


\section{Isabella Alves Lamas}

\isaalamas@unilab.edu.br

ORCiD: https://orcid.org/0000-0003-2145-1604

\section{Stefania Barca}

\sbarca68@gmail.com

ORCiD: https://orcid.org/0000-0002-8136-3369

\section{Bernadete Souza Ferreira}

$\square$ bernabela68@yahoo.com.br

\section{Ivonne Yanez}

$\checkmark$ ivonney@accionecologica.org

How to cite: LAMAS, I.; BARCA, S.; FERREIRA, B.; YANEZ, I. Horizontes Ecofeministas. Ambiente \& Sociedade. São Paulo, v. 24, p. 1-13, 2021. 


\title{
Horizontes Ecofeministas
}

\author{
Bernadete Souza Ferreira \\ Isabella Lamas \\ Ivonne Yanez \\ Stefania Barca
}

São Paulo. Vol. 24, 2021

Narrativas e reflexões: Insurgências Decoloniais e Horizontes Emancipatórios
Resumo: As ecologias políticas decoloniais têm como alguns de seus dilemas centrais conseguir avançar e articular, além do apontamento das críticas e identificação dos problemas, propostas transformadoras, reflexões acerca das práticas emancipatórias e, sobretudo, imaginar cenários e horizontes possíveis. As ideias destes horizontes estão articuladas nessa narrativa por três mulheres ambientalistas e feministas que atuam em diferentes contextos sociais: Bernadete Souza Ferreira Santos, camponesa, ialorixá, educadora popular que atua na região de Ilhéus, no sul da Bahia, e especialista em Educação do Campo e Agroecologia pela USP; Ivonne Yanez, ativista ambiental do Equador e uma das fundadora da organização Accíon Ecologica; e, Stefania Barca, italiana de Nápoles, pesquisadora do Centro de Estudos Sociais da Universidade de Coimbra. Elas juntas nos mostram que os caminhos para horizontes emancipatórios têm como um de seus pontos centrais a intersecção entre a Ecologia Política e os feminismos.

Palavras-chave: Ecofeminismo; ecologia política; antropoceno; alternativas; agroecologia; justiça ambiental

Como citar: LAMAS, I.; BARCA, S.; FERREIRA, B.; YANEZ, I. Horizontes Ecofeministas. Ambiente $\mathbb{\&}$ Sociedade. São Paulo, v. 24, p. $1-13,2021$. 


\title{
Horizontes Ecofeministas
}

\author{
Bernadete Souza Ferreira \\ Isabella Lamas \\ Ivonne Yanez \\ Stefania Barca
}

São Paulo. Vol. 24, 2021

Narrativas y reflexiones: Insurgencias Decoloniales y Horizontes Emancipatórios
Resumen: Las ecologías políticas decoloniales tienen como algunos de sus dilemas centrales poder avanzar y articular, además de señalar críticas e identificar problemas, propuestas transformadoras, reflexiones sobre prácticas emancipatorias y, sobre todo, imaginar escenarios y horizontes posibles. Las ideas de estos horizontes son articuladas en esta narrativa por tres mujeres ambientalistas y feministas que actúan en diferentes contextos sociales: Bernadete Souza Ferreira Santos, campesina, ialorixá, educadora popular que trabaja en la región de Ilheus, sur de Bahía, y especialista en educación rural y agroecología de la USP; Ivonne Yanez, activista ambiental de Ecuador y una de las fundadoras de la organización Accíon Ecologica; y, Stefania Barca, italiana de Nápoles, investigadora del Centro de Estudios Sociales de la Universidad de Coimbra. Juntos nos muestran que los caminos hacia horizontes emancipatorios tienen como uno de sus puntos centrales la intersección entre la ecología política y los feminismos.

Palabras-clave: Diversidad Biológica, Evaluación de Impacto Ambiental, Uso de la Tierra.

Como citar: LAMAS, I.; BARCA, S.; FERREIRA, B.; YANEZ, I. Horizontes Ecofeministas. Ambiente \& Sociedade. São Paulo, v. 24, p. 1-13, 2021.

DOI: http://dx.doi.org/10.1590/1809-4422asoc20210153vu2021L5NR 